Vol..5, No.2.2019

Doi: https://doi.org/10.24198/cosmogov.v5i2.23293

http://jurnal.unpad.ac.id/cosmogov/index

\title{
RELASI POLITIK UANG DAN PARTY-ID DI INDONESIA
}

\author{
Iradhad Taqwa Sihidi ${ }^{1}$ \\ Laeli Nur Khanifah ${ }^{1}$ \\ Achmad Apriyanto Romadhan ${ }^{1}$ \\ Departemen Ilmu Pemerintahan, Fakultas Ilmu Sosial dan Ilmu Politik \\ Universitas Muhammadiyah Malang \\ Jl. Bendungan Sutami No.188, Sumbersari, Kec. Lowokwaru, Kota Malang, Jawa Timur 65145, \\ Indonesia \\ Email:iradhad@umm.ac.id
}

Submitted: August 21, 2019; Reviewed: November 18, 2019; Published: November 24, 2019

\begin{abstract}
ABSTRAK
Tulisan ini secara spesifik melihat implikasi serius dari rendahnya Party-ID terhadap masivnya praktek politik uang di Indonesia. Prosesi demokrasi elektoral di Indonesia bekerja dengan logika padat modal sehingga kekuatan finansial menjadi salah satu faktor determinan dalam kemenangan kandidat politik. Hal ini beririsan secara bersamaan dengan terjadinya proses deideologisasi yang berlangsung secara masif ditubuh partai politik dan pemilih sehingga tingkatan Party-ID menjadi lemah. Metode penelitian yang digunakan adalah kualitatif dengan pendekatan studi literatur. Data utama yang digunakan berasal dari jurnal, buku, maupun internet. Penelitian ini menunjukan bahwa gagalnya fungsi representasi politik (artikulasi dan agregasi kepentingan) yang ditampilkan partai politik membuat ikatan kedekatan ideologis (Party-ID) dengan masyarakat menjadi begitu rapuh. Hilangnya kohesi ideologis tersebut turut andil menguatkan tipologi floating mass yang seringkali harus diikat kembali melalui pendekatan politik uang ketika momen elektoral hadir (Pemilu dan Pilkada). Memperkuat fungsi intermediasi Partai Politik melalui reformasi kelembagaan dan kerjakerja politik ideologis adalah salah satu solusi strategis memutus mata rantai politik uang di Indonesia.
\end{abstract}

Kata Kunci: massa mengambang; partai politik; party-ID; politik uang

\begin{abstract}
This paper specifically looks at the serious implications of the low number of Party-IDs on the importance of the practice of money politics in Indonesia. Electoral democracy procession in Indonesia works with capital-intensive logic so that financial strength is one of the determinant factors in the victory of political candidates. This coincided with the de-idealization process that took place massively in the body of political parties and voters so that the level of Party-ID was weakened. The research method used is qualitative with a literature study approach. The main data used comes from journals, books, and the internet. This research shows that the failure of the function of political representation (articulation and aggregation of interests) displayed by political parties makes the ideological bond (Party-ID) close to the community so fragile. The loss of ideological cohesion has contributed to the strengthening of the floating mass typology which often must be tied back through the approach of money politics when the electoral moment is present (elections and local elections). Strengthening the intermediary function of political parties through institutional reform and ideological-political work is one of the strategic solutions to break the money politics in Indonesia.
\end{abstract}

Keywords: floating mass;money politics; party ID; political parties

\section{PENDAHULUAN}

Tulisan ini melihat maraknya politik uang dalam proses elektoral di
Indonesia yang disebabkan lemahnya

Party-ID. Partai politik mengalami keterputusan relasi ideologis yang dalam 
Vol..5, No.2, 2019

Doi: https://doi.org/10.24198/cosmogov.v5i2.23293

http://jurnal.unpad.ac.id/cosmogov/index

dengan banyak pemilih sehingga uang menjadi faktor penting untuk mendapatkan kembali dukungan. Interaksi pragmatis itulah yang belakangan ini menjadi wajah buruk praktek demokrasi di Indonesia.

Reformasi konsitusional berhasil menciptakan proses demokratisasi politik dimana pendulum kekuasaan tidak lagi dimonopoli tunggal oleh negara. Negara represif nan totaliter ala Orde Baru yang begitu dominan dalam semua pengelolaan dan distribusi kekuasaan /sumberdaya politik tumbang berganti dengan era demokratik dimana ada peningkatan kontrol dan partisipasi publik. Pengejewantahan model demokratik tersebut dalam perjalananya dapat dijumpai salah satunya dengan diadakanya proses pemilihan pejabat pemerintahan (Presiden, Kepala Daerah, Anggota Legislatif). Pemilihan merupakan hakekat utama dari berlangsungnya demorasi moderen (Philippe C. Schmitter, 1991). Tujuanya mencari representasi politik yang lebih substantif dan bertanggungjawab. Tipe ini bekerja dalam arena demokratis dimana pemimpin yang terpilih bekerja mewakili secara sungguh-sungguh kepentingan rakyatnya (Pitkin, 1967)

Dalam rezim demokratis ada kewajiban melakukan sirkulasi pergantian pemimpin melalui proses akuntabel dan transparan. Secara teoritis proses demokratisasi yang merupakan sebuah fase transformasi otoritarianisme menuju demokrasi akan berlangsung sempurna manakala terjadi proses pemilu yang berkualitas dengan menghasilkan pemimpin politik yang pro pada kesejahteraan publik. Harapan yang sangat sulit mengingat lazimnya demokratisasi di negara-negara dalam fase ini memerlukan proses perbaikan yang cukup panjang khususnya untuk memerangi praktek korupsi (Eliska Drapalova, 2019).

Dalam fase transisi politik tersebut minimal diperlukan 3 kali pemilihan umum untuk memperoleh kualitas demokrastis yang ideal (Huntington, 1984). Tesis Hutington ini sebetulnya menyasar proses demokratisasi di dunia ketiga pasca rezim otoriter yang jika dilakukan sesuai prosedur dan etis akan menghasilkan pemerintahan berbasis good governance, partisipasi masyarakat yang meningkat dan kuat serta sistem kepartaian yang akutabel. Pemilu selanjutnya menjadi arena strategis untuk melihat sejauhamana keberhasilan proses konsolidasi demokrasi khususnya di Indonesia.

Dalam lanskap politik Indonesia, pasca Orde Baru tercatat telah dilakukan 5 (lima) kali pemilihan Umum yakni 1999, 2004, 2009, 2014 dan 2019. Adapun untuk Pemilihan Kepala Daerah (Pilkada) telah berlangsung selama 13 tahun (2005) dengan berbagai macam capaian dan problematikanya. Seperti diketahui bersama proses kontestasi politik berbiaya mahal ini belum mampu menjawab citacita reformasi dan ekpektasi publikmendapatkan pemimpin politik yang berorientasi pada agenda-agenda kesejahteraan publik. Mandeknya harapan ini menjadi lumrah mengingat proses pemilu yang kita jalani sarat dengan dengan segudang persoalan. Mulai dari manipulasi suara, politik uang, konflik sosial, intimidasi dan kekerasan. Anomali tersebut menunjukan bahwa proses 
Vol..5, No.2, 2019

Doi: https://doi.org/10.24198/cosmogov.v5i2.23293

http://jurnal.unpad.ac.id/cosmogov/index

pemilu/pilkada belum terlembaga dengan baik sehingga sulit diharapkan menghasilkan output kepemimpinan politik yang bervisi keadilan sosial.

Kajian ini fokus memotret fenomena politik uang sebagai konsekuensi negatif pemilu/pilkada di Indonesia. Politik uang sebetulnya merupakan lanjutan dari pragmatisme politik masyarakat Indonesia yang terus berkembang pasca reformasi politik 1998. Terbukanya keran partisipasi politik di satu sisi selain memberikan angin segar bagi keterlibatan publik dalam proses politik juga berefek pada terbentuknya pemilih pragmatis yang terafiliasi secara ideologis dalam kategori floating mass. Pemilih kategori ini tidak memiliki preferensi politik yang kaku, rentan berubah dan kerap dapat dimobilisasi dengan uang.

Politik uang pada giliranya bertransformasi menjadi salah satu patologi demokrasi elektoral di Indonesia. Bekerja efektif dalam suasana psikologis pemilih yang belum memiliki literasi kritis dalam memilih. Preferensi politik yang tidak berpijak pada rasionalitas mengakibatkan pilihan politik seringkali didasarkan atas dasar pertimbangan jangka pendek yang salah satunya adalah uang. Temuan riset Politics and Government Research Center (PolGov) UGM Yogyakarta bekerjasama dengan Coral Bell School of Asia Pasific Affairs di Australian National University (ANU) menyimpulkan bahwa Politik Indonesia adalah uang (Aspinal, 2016).

Tesis diatas memang cukup sahih mengingat momen elektoral kita faktanya kental dengan politik uang. Dari tahun 1999-2019 tercatat kasus politik dalam pemilu Indonesia jika diakumulasi mencapai 669 kasus. Pun dalam Pilkada dengan mengambil sampel Pilkada serentak 2015 dan 2017 mencapai 1.529 kasus. Modusnya pun semakin canggih dan beragam dengan melibatkan banyak aktor mulai dari Wakil Bupati, tim sukses dan masyarakat biasa.

Kedua temuan diatas sebetulnya mengkofirmasi asumsi bahwa dalam setiap momen elektoral baik ditingkat lokal maupun nasional uang merupakan faktor determinan dalam keterpilihan seorang kandidat. Kajian yang dilakukan Pramono Anung menyebutkan seorang kandidat mengeluarkan biaya antara 300 Juta-6 Miliar untuk menjadi anggota DPR (Anung, 2013). Nominal tersebut tentunya bertambah mengingat penelitian tersebut dilakukan sebelum Pemilu tahun 2014. Maka politik berbiaya tinggi ini selanjutnya berefek pada penyalahgunaan kekuasaan pejabat ketika berkuasa (Tan, 2018). Preseden ini bisa dillihat dari banyaknya pejabat politik yang terjerat kasus korupsi dengan dalih mengembalikan modal pencalonan.

Kajian Penelitian dan Pengembangan (Litbang) Kemendagri pada tahun 2015 dalam melakukan evaluasi pilkada serentak menyebutkan biaya yang dihabiskan setiap kandidat berkisar 25-30 Miliar untuk Bupati/Walikota dan 20-100 Miliar untuk Gubernur. Sedangkan untuk Pemilihan Presiden (Pilpres) kajian Majalah Forbes (2013) menyebutkan seorang kandidat setidaknya membutuhkan dana sekitar 7 Triliun untuk berkompetisi. Biaya tersebut digunakan untuk banyak hal yang salah 
Vol..5, No.2, 2019

Doi: https://doi.org/10.24198/cosmogov.v5i2.23293

http://jurnal.unpad.ac.id/cosmogov/index

satunya untuk praktek politik uang. Lebih spesifik dalam konteks pemenangan kepala daerah kajian yang dilakukan oleh Perludem (2015) menyebutkan setidaknya seorang kandidat harus mempersiapkan logistik yang memadai untuk 4 hal; membeli rekomendasi pencalonan dari partai politik, menyewa jasa konsultan politik, membiaya mesin politik dan kampanye politik dan melakukan politik uang..

Besarnya biaya politik yang harus dikeluarkan oleh seorang kandidat tidak terlepas dari kebutuhan untuk melakukan politik uang. Dalam tradisi politik Indonesia politik uang seperti menjadi sebuah tindakan politik pemenangan yang harus dilakukan. Para kandidat perlu menyediakan anggaran khusus untuk melakukan politik uang. Celakanya ini berbanding lurus dengan permisifnya masyarakat pada politik uang. Survei Charta Politica 19-25 Maret 2019 menyebutkan bahwa 45,6 persen responden menyatakan memaklumi praktik politik uang. Sementara 39,1 persen tidak memaklumi, dan 15,4 persen tidak tahu atau tidak menjawab (Ihsanuddin, 2019)

Salah satu alasan logis dibalik praktek politik uang yang masiv bertautan erat dengan tipe pemilih mengambang (floating mass) yang pragmatis. Secara sederhana, pragmatis merujuk pada orientasi sifat dan sikap manusia lebih cenderung bersifat praktis, terbingkai, dan kaku. John Dewey (1859-1952), seorang penganut madzhab pragmatisme menjelaskan bahwa sifat ini dapat timbul dan berkembang disebabkan oleh relasi intensif antara jika ada organisme/manusia dengan lingkungannya. Dalam melihat kebenaran, aliran ini mengukurnya berdasarkan kemanfaatan bagi manusia (A37, 2018).

Dalam konteks politik, istilah pragmatisme mengalami operasionalisasi yang lebih negatif. Ada pergeseran makna pragmatisme dalam kehidupan politik dengan maksud untuk menunjukan orientasi jangka pendek dari aktor politik untuk dapat memenangkan persaingan politik. Tendensi negatif ini muncul sebagai akibat dari nafsu berkuasa, dan seringkali orientasi ini membawa para aktor politik ke arah sikap yang lebih mementingkan tujuan untuk berkuasa ketimbang apa saja yang akan dilakukan setelah berkuasa (Firmanzah, 2011).

Dalam konteks pemilih atau masyarakat, pragmatisme tercermin dari penentuan preferensi politik (dukungan suara) yang didasarkan atas pertimbangan transaksional. Dalam hal ini siapa yang dapat memberikan keuntungan ekonomi jangka pendek. Disinilah politik uang bekerja dengan membeli dukungan suara pemilih. Itulah sebabnya sering kali yang menjadi objek politik uang adalah masyarakat kelas ekonomi bawah. Mereka inilah yang rentan dieksploitasi politik uang dengan alasan kesulitan ekonomi (Priyono \& Hamid (ed) 2014).

Pragmatisme pemilih tidak dapat dilepaskan dari rendahnya ikatan ideologis pemilih dengan partai politik (Party-ID). Fungsi artikulasi kepentingan, agregasi kepentingan dan representatif gagal diperankan oleh partai politik sehingga masyarakat (pemilih) kehilangan dukungan sehingga loyalitas tidak terbentuk. Floating 
Vol..5, No.2, 2019

Doi: https://doi.org/10.24198/cosmogov.v5i2.23293

http://jurnal.unpad.ac.id/cosmogov/index

mass dengan karakteristik pragmatis sangat ditentukan oleh rapuhnya jalinan ideologis dengan partai politik sehingga mereka tidak memiliki loyalitas kuat pada satu sikap politik. Pilihan mereka kemudian sangat rentan berubah dan uang menjadi salah satu instrumen yang dinantikan oleh pemilih untuk mendapatkan suara mereka.

Kajian-kajian terdahulu soal politik uang di Indonesia sebetulnya masih terbatas khususnya ketika mengkerangkai dimensi politik uang dari aspek Party-ID. Kompilasi hasil riset yang dituangkan dalam buku berjudul Politik Uang di Indonesia (2015) merekam dengan jelas bagaimana politik uang menjadi aktivitas kampanye pembelian suara yang lazim digunakan oleh banyak politisi calon DPRD agar bisa terpilih. Politik uang dengan ragam modusnya (Pork Barrel, suap, program-program sosial seperti pengobatan gratis, gathering, janji proyek, dil) merupakan model sistematis dan sangat digemari oleh politisi untuk membangun patronase dan klientelisme (Mada Sukmajati, 2015). Kekuatan politik uang ternyata menjadi efisien dilaksanakan dalam Pemilihan anggota Dewan Perwakilan Rakyat Daerah (DPRD) dan kepala daerah. Riset Edward Aspinall dan kawan-kawan menemukan bahwa serangan fajar sebagai bentuk operasi politik uang ampuh dalam memoblisasi suara (Edward Aspinal, 2019). Secara spesifik riset dengan skup politik lokal ini menemukan bahwa 60-80 persen pemilih memberikan suaranya pada kandidat DPRD yang memberikan mereka uang atau barang fisik lainya. Adapun untuk pemilihan kepala daerah tercatat 40-60 persen pemilih mengijinkan suara mereka ditukar dengan uang atau barang. Aspinal selanjutnya menjelaskan bahwa politik uang ini akan efektif jika melibatkan broker. Mereka disebut sebagai pialang politik menjadi agen distributor politik uang yang seringkali digunakan oleh politisi untuk membeli dukungan pemilih (Edward Aspinal, 2014). Para broker yang menjadi tokoh berpengaruh ini dijanjikan timbal-balik yang biasanya berbentuk misalnya pembuatan jalan, bantuan sosial dan lain-lain.

Kajian lebih detail dilakukan oleh (Burhanuddin Muhtadi, 2013) untuk memotret fakta masivnya politik uang bukan hanya dari penjelasan fenomena patron-klien yang memang biasa dianalisis oleh penelit sebelumnya. Burhanuddin Muhtadi meskipun tidak secara keseluruhan dan detail menyampaikan bahwa rendahnya ikatan ideologis dengan partai politik oleh masyarakat (Party-ID) juga berkontribusi langsung pada terjadinya politik uang di tingkat masa. Semakin rendah tingkatan Party-ID masyarakat semakin besar potensi penerimaan mereka pada politik uang.

Penelitian ini mengambil sudut yang agak berbeda dengan tetap menempatkan Party-ID sebagai faktor dominan dibalik maraknya politik uang. Berbeda dengan argumentasi penelitian Burhanuddin Muhtadi yang dilakukan pada 2013 dan tetap memakai patron-klien dan party-ID, tulisan ini berlangsung pada konteks kontemporer setelah 2013 dimana penulis melihat apakah ditengah perubahan konfigurasi politik dan model pemilihan 
Vol..5, No.2, 2019

Doi: https://doi.org/10.24198/cosmogov.v5i2.23293

http://jurnal.unpad.ac.id/cosmogov/index

terjadi perubahan cara pandang atau karakteristik pemilh terhadap politik uang.

\section{METODE}

Proses elektoral di Indonesia yang berlangsung secara langsung pasca Orde Baru identik dengan politik uang. Alih-alih reformasi politik diharapkan mampu membuat proses pemilu berlangsung lebih terbuka dan bertanggungjawab sebaliknya yang terjadi justru politik uang semakin masiv terjadi. Salah satu sebab utamanya adalah rendahnya Party-ID sehingga membuat biaya politik menjadi mahal. Untuk memperjelas asumsi tersebut penelitian ini menggunakan jenis penelitian kualitaif yang bersifat studi literatur. Datadata utama didapatkan melalui studi kepustakaan/literatur baik berupa buku, jurnal, koran, majalah dan internet yang berkaitan langsung dengan Fenomena Party-ID dan politik uang (Sutrisno Hadi, 2001). Guna memberikan kesimpulan yang relevan, penelitian ini menggunakan analisa model deskriptif - sebuah pendekatan yang fokus pada penyelidikan secara menyeluruh dan kritis sebuah fenomena dalam hal ini untuk melihat secara nyata relasi politik uang dan Party-ID dalam politik elektoral Indonesia. Party-ID menjadi landasan teoritis untuk memeriksa secara detail praktek politik uang dalam kehidupan elektoral di Indonesia.

\section{HASIL DAN DISKUSI}

Dalam khazanah ilmu politik, konsep partai politik pertama kali digunakan sekitar abad ke 19 untuk menjelaskan sistem politik yang kompetitif (Amstuzt, 1982: 222 dalam Nurjaman,
2018:35). Partai politik adalah salah satu instrumen memperoleh kekuasaan yang bertarung secara terbuka dalam sistem politik yang kompetitif.

Dalam perkembangan selanjutnya istilah partai politik didefinisikan dengan banyak penjelasan. Partai Politik dipandang sebagai kelompok otonom warga negara yang bertujuan mengajukan nominasi dan bersaing dalam pemilu dengan harapan mendapatkan kekuasaan di pemerintahan melalui jabatan publik. Sigmund Neumann dalam (Labolo \& Ilham, 2015:11) merumuskan partai sebagai:

'a political party is the articulate organization of society's active political agents, those who are concerned with the control of government power and who compete for popular support with another group or groups holding divergent views",

Carl J. Friedrich dalam (Labolo \& Ilham, 2015:12),

'A political party is a group of human beings, stably organized with the objective of securing or maintaining for its leaders the control of a government, with the further objective of giving to members of the party, through such control ideal and material benefits and adventages".

Untuk mempertegas dan memperjelas konsep partai politik, Frank J Sorous (Labolo \& Ilham, 2015:13) mengemukanan unsur-unsur pokok dalam partai politik;

1. Pemilihan umum menjadi orientasi/tujuan utama dalam pengembangan organisasi

2. Bersifat inklusif agar berbagai kelompok masyarakat dapat ikut bergabung 
Vol..5, No.2. 2019

Doi: https://doi.org/10.24198/cosmogov.v5i2.23293

http://jurnal.unpad.ac.id/cosmogov/index

3. Panggung atau kehidupan politik menjadi tujuan utama dalam mewujudkan tujuan partai politik

4. Organisasi dikelola secara sistematis untuk mendukung stabilitas dan keberlanjutan organisasi dengan menempatkan loyalitas anggota sebagai basisnya.

Adapun partai politik memiliki fungsi; perwakilan, pembentukan dan rekruitmen elite, perumusan tujuan, artikulasi dan agregasi kepentingan, sosialisasi dan mobilisasi dan pengorganisasian pemerintahan (Andre Heywood, 2014:399). Khusus dalam pemilu, partai politik dimaknai sebagai agen perwakilan yang melakukan interkasi politik dengan masyarakat, meminta dukungan untuk mendapatkan dukungan suara dalam pemilihan (Sergiu Gherghina, 2015:21).

Partai Politik merupakan infrastruktur politik yang dalam wajah demokrasi Indonesia kontemporer mengalami sentimen/apreasi paling negatif di mata publik. Survei opini publik yang dilakukan oleh beberapa lembaga survei nasional menunjukan partai politik berada dalam titik konstan sebagai lembaga representasi paling terburuk di mata publik. Selama 4 (empat) tahun terakhir partai politik bersama Dewan Perwakilan Rakyat (DPR) menjadi lembaga yang paling buruk dalam hal kepuasan publik.

Pada tahun 2015 Survei yang dilakukan Poltracking Indonesia, partai politik memperoleh angka 63,3 persen sebagai institusi demokrasi yang tidak memuaskan kepentingan publik (Gabrillin, 2015). Survei dengan total 1.200 responden yang diadakan dalam kurun waktu 23-31 Maret 2015 dengan margin error 2,9 persen merekam kekecewaan publik atas kinerja partai politik yang tidak memperjuangkan kepentingan rakyat. Rendahnya kepuasaan publik yang terekam dalam survei tersebut didasarkan atas pertimbangan lemahnya fungsi artikulasi wakil partai politik di Dewan Perwakilan Rakyat (DPR) dan Kabinet serta maraknya kasus korupsi yang melibatkan kader partai politik. Publik melihat bahwa partai politik hanya bekerja untuk kepentingan dirinya sendiri. Janji tentang peningkatan kapasitas kelembagaan dan kaderisasi yang terbuka tidak pernah terwujud. Fungsi partai politik kemudian menjadi sangat tidak optimal. Partai Politik lebih dikenal dengan orientasi kekuasaanya yang tinggi ketimbang bekerja demi mengawal kepentingan masyarakat.

Tren serupa juga berlangsung pada tahun 2016. Survei Indikator Politik Indonesia pada tanggal 18-29 Januari 2016 menemukan bahwa kepercayaan publik pada partai politik sangat rendah hanya 39, 2 persen (Indikator, 2016). Pada tahun 2017, Poltracking kembali melakukan survei mengenai kepuasan publik pada institusi negara. Dengan melibatkan 2.400 responden yang merata tersebar diseluruh (34) propinsi di Indonesia menyebutkan hanya 34 persen masyarakat Indonesia yang positif mengapresiasi kinerja partai politik. Angka ini sama dengan DPR yang sebetulnya juga merupakan representasi Partai Politik (Tashandra, 2017).

Terakhir pada tahun 2018 Lembaga Survei Alvara Research Center melakukan survei dengan fokus melihat 
Vol..5, No.2. 2019

Doi: https://doi.org/10.24198/cosmogov.v5i2.23293

http://jurnal.unpad.ac.id/cosmogov/index

tingkat kepuasan publik pada institusiinstiusi kunci negara seperti TNI, Polri, KPK, DPR, MPR dan partai politik. Hasillnya bervariatif dengan TNI dan KPK memperoleh 88,3 persen dan 82,4 persen. Keduanya secara berurutan merupakan lembaga yang paling diapresiasi oleh publik. Selanjutnya Polri 78,8 persen, BIN 75,0 persen, KPU 75,0 persen, partai politik 64,3 persen, MPR 57,0 persen, dan DPR 51,8 persen. Survei tersebut menggunakan rentang penilaian yakni $0 \%$ - 33 persen (E), 34 persen -50 persen (D), 51 persen -66 persen (C), 67 persen -83 persen (B), dan 83 persen - 100 persen (A) (Trian, 2018).

Fakta diatas mengkonfirmasi ketidakpuasan publik dengan kinerja (DPR) dan partai politik, institusi yang selama ini merepresentasikan diri sebagai penyambung aspirasi rakyat. Kinerja dua lembaga itu dianggap buruk dibandingkan lembaga lainnya. Gejala deparpolisasi seperti ini terbentuk akibat lemahnya fungsi-fungsi dasar dan utama yang diperankan oleh partai politik selama ini.

Ditahun yang sama 2018, Charta Politica dan Lembaga Ilmu Pengetahuan Indonesia (LIPI) Juga melakukan survei pemetaan yang sama. Charta Politica menyebutkan bahwa 44,1 persen responden/masyarakat tidak percaya dengan aktivitas partai politik. Survei ini menggunakan metode tanya jawavb via telepon di delapan (8) kota dengan melibatkan 800 responden (Prakoso, 2018).

Adapaun Survei yang diadakan oleh Lembaga Ilmu Pengetahuan Indonesia (LIPI) menunjukan bahwa partai politik menempati lembaga demokrasi dengan kinerja paling buruk. Angkanya sangat rendah yakni 57,9 persen responden menyatakan kinerja partai politik buruk dan 25,5 persen menyebut sangat buruk. Hanya $13,10 \%$ yang menyatakan puas. Ketidakpuasan terhadap partai politik turut merembet pada institusi lain yang dihuni kader partai politik yakni Dewan Perwakilan Rakyat (DPR) dengan kepuasan hanya 23,45 persen, Dewan Perwakilan Daerah (DPD) 28,28 persen, DPRD kabupaten/kota 31,72 persen, dan DPRD provinsi 33,10 persen. Survei ini cukup unik namun tetap representatif sebagai gambaran opini publik. Responden yang dipilih melibatkan 145 pakar dengan keahlian yang berbeda-beda. Mulai dari ahli politik, ekonomi, sosial-budaya, dan pertahanan keamanan. Survei ini berlangsung selama 3 bulan (April-Juli 2018) yang dilakukan di 11 Propinsi (Jurnaliston, 2018).

\section{Politik Uang}

Kajian soal politik uang belakangan ini menjadi perhatian serius di negara-negara pasca otoriter dan berkembang. Pasalnya tumbangnya rezim despotik nan represif berhasil menciptakan era keterbukaan politik yang salah satunya ditandai dengan sistem multi partai yang ekstrem. Implikasinya terlihat pada semakin menjamurnya partai politik dengan tawaran ideologis yang hampir sama. Kemiripan itulah yang membuat partai politik tidak memiliki positioning yang kuat dan secara tidak langsung membuat pemilih menjadi gamang. Persoalan inilah yang selanjutnya berkelindan dengan masivnya politik uang di Indonesia pasca reformasi. 
Vol..5, No.2. 2019

Doi: https://doi.org/10.24198/cosmogov.v5i2.23293

http://jurnal.unpad.ac.id/cosmogov/index

Sistem multi-partai yang dianut di Indonesia sedari awal memang bermasalah khususnya pada kaburnya batas ideologis antar partai politik. Masyarakat dihadapkan pada pilihan politik yang begitu beragam ditengah rasionaltas memilih yang belum kuat. Akibatnya partai politik yang memiliki kekuatan modal finansial melimpah sebab dikendalikan oleh kaum oligarkis memanfaatkan celah tersebut dengan menjadikan uang sebagai salah satu alternatif dalam memobilisasi suara. Rapuhnya basis pengetahuan dalam memilih membuat pemilih menjadi sangat transaksional sebab mendasarkan pilihan politiknya berdasarkan imbalan materi yang diberikan partai politik beserta anarsirnya.

Sebelum lebih jauh politik uang perlu didefinisikan terlebih dahulu. Politik uang kerap dimaknai sebagai sarana mempengaruhi masyarakat/pemilih dengan menggunakan imbalan materi dalam proses kontestasi kekuasaan. Proses ini lazim dikenal degan praktek jual beli suara. Masyarakat diberikan uang oleh sesorang/aktor politik dengan tujuan memilih mereka pada saat pencoblosan.

Politik uang terbukti ampuh dalam menarik suara pemilih. Khsususnya dengan tipikal pemilih mengambang (floatingg mass) yang bersikap pragmatis dan tidak memiliki kedekatan emosional dan ideologis (Party-ID) yang kuat dengan partai politik. Pemilih dengan klasifikasi seperti inilah yang kerapkali menjasi sasaran empuk bagi kandidat untuk melakukan kampanye politik yang efektif berbasis uang. Tidak perlu menyampaikan gagasan dan visi pencalonan yang detail dan menjawab persoalan masyarakat, cukup dengan memberikan uang suara dapat diakumulasi.

Floating mass sebetulnya berawal dari kebijakan kekuasaan zaman Orde Baru dengan maksud mengisolir partai politik khususnya PDI dan PPP di tingkat akar rumput. Harapanya kedua lawan Politik Orde Baru tersebut tidak memiliki masa ideologis yang kuat sehingga mudah untuk dikalahkan dalam setiap momen pemilu. Saat itu Orde Baru secara sistematis merekaya klasifikasi pemilih (floating mass) agar masyarakat tidak memiliki ikatan ideologis dengan partai PDI dan PPP sehingga lebih mudah untuk dimobilisasi oleh kekuatan Birokrasi dan ABRI untuk mendukung Orde Baru (Golkar).

$$
\text { Dalam catatan Indonesia }
$$

Coruppction Watch (ICW) praktek politik uang selalu berlangsung dalam setiap pemilu Indonesia. Pada pemilu 1999 terjadi 62 kasus, pemilu 2004 meningkat tajam menjadi 113 kasus, pemilu 2009 naik menjadi 150 kasus dan pemilu 2014 sebanyak 313 kasus (RFQ, 2014). Adapun untuk pemilu 2019 sebanyak 31 kasus (CNN, 2019).

Fenomena serupa juga terjadi di Pemilihan Kepala Daerah (Pilkada). Dalam catatan yang ada, Pilkada serentak 2015 dari total laporan dugaan Tindak Pidana Pilkada (TPP) 1.090 kasus, 929 diantaranya adalah politik uang atau lebih lazim dikenal dengan istilah "serangan fajar" (A15, 2017). Temuan Bawaslu juga mengkonfirmasi kecenderungan pemilu tersebut meskipun dengan data yang sedikit berbeda. Dalam temuannya, Bawaslu menemukan 92 kasus politik uang yang 
Vol..5, No.2, 2019

Doi: https://doi.org/10.24198/cosmogov.v5i2.23293

http://jurnal.unpad.ac.id/cosmogov/index

tersebar di 21 kabupaten dan 10 propinsi saat masa kampanye dilakukan. Laporan tersebut juga menemukan setidaknya 311 kasus politik uang terjadi pada masa tenang di 16 propinsi dan 25 kabupaten/kota. Sedangkan pada hari pelaksanaan terjadi 90 kasus politik uang yang terjadi di 22 kabupaten pada 12 propinsi (Abdul Aziz, 2016).

Dalam pilkada serentak 2017 di 101 daerah, Bawaslu menemukan 600 kasus dugaan politik uang. Bentuknya berupa uang dan sembako yang dilakukan oleh relawan calon dan perseorangan (Lutfy Mairizal Putra, 2017). Adapun Pilkada serentak 2018 yang berlangsung di 171 wilayah Bawaslu memproses 31 dugaan kasus politik uang yang terbanyak terjadi di Sulawesi Selatan (8 kasus).

Dari sejumlah kasus di atas sebetulnya menunjukan fenomena gunung es. Masih banyak kasus yang terjadi namun tidak dapat ditindak dengan berbagai macam alasan. Biasanya masyarakat enggan melaporkan karena mengganggap hal tersebut sebagai sesuatu yang wajar bukan pelanggaran. Bawaslu dan kepolisian juga kurang maksimal dalam melakukan pemantauan dan pengawasan.

Di sisi lain temuan kasus diatas sebetulnya juga beririsan dengan respon masyarakat terhadap praktek politik uang. Founding Father House (FFH) melakukan kajian dalam kurun waktu 2010-2016 untuk melihat sejauhaman tingkat permisifnya masyarakat pada praktek politik uang yang dilakukan kandidat beserta tim suksesnya. Hasilnya menunjukan fluktiatuf meskipun tetap berkisar pada rentang 50-60 \% yang berarti mayoritas masyarakat menerima/ permisif pada politik uang. Pada tahun 2010 angkanya 64,5 persen, 201161 persen, 201253 persen, 201358,5 persen, 201466 persen, 201563 persen dan 2016 61,8 persen. Temuan ini sebetulnya berkorelasi positif dengan temuan riset yang menunjukan pada tahun 2010 sebanyak 35,5 persen responden menolak politik amplop (uang), naik menjadi 39 persen di 2011, naik signifikan ke 47 persen di 2012, turun menjadi 41,5 persen di 2013, turun ke angka 34 persen di 2014, kembali naik menjadi 37 persen di 2015 dan tetap kembali naik meskipun kecil di tahun 2016 menjadi 38,2 persen (A15, 2017).

Temuan serupa juga didapatkan melalui survei yag dilakukan Centre for Strategic and International Studies (CSIS) Mei 2018. Dalam survei pra-Pemilu Kepala Daerah (Pilkada) Serentak 2018. Meskipun konteksnya pada pemilih di Jawa Barat, Jawa Tengah, Sumatera Utara dan Sulawesi Selatan namun setidaknya survei ini dapat merefleksikan kondisi nasional secara umum. Hasilnya bervariatif namun dengan interval yang sangat dekat. Di Jawa Barat sebesar 40,5 persen responden akan menerima barang/uang dari kandidat melalui tim sukses, di Jawa Tengah sebesar 48,7 persen. Sulawesi Selatan sebesar 43,9 persen dan 40,05 persen di Sumatera Utara.

Negara melalui instrumen hukumnya sebetulnya telah melakukan banyak upaya untuk mencegah politik uang. Dalam Undang-undang nomor 10 tahun 2016 (pasal 73 ayat 2) tentang pilkada pasangan calon (paslon) jika terbukti secara meyakinkan melakukan 
Vol..5, No.2, 2019

Doi: https://doi.org/10.24198/cosmogov.v5i2.23293

http://jurnal.unpad.ac.id/cosmogov/index

pembelian suara (politik uang) akan didiskualifikasi meskipun telah dinyatakan menang saat pemilihan. Pemberi dan penerima politik uang pun bisa mendapatkan hukuman pidana Pasal 73 Ayat (4) dipidana dengan pidana penjara paling singkat 36 (tiga puluh enam) bulan dan paling lama 72 (tujuh puluh dua) bulan dan denda paling sedikit Rp 200.000.000 (dua ratus juta rupiah) dan paling banyak Rp 1.000.000.000 (satu miliar rupiah). Ancaman serupa juga diatur dalam Undang-undang Nomor 7 Tahun 2017 tentang Pemilihan Umum. Peserta pemilu yang terbukti melakukan politik uang diancam pidana maksimal 4 tahun. Jikapun terpilih mereka dapat dibatalkan.

\section{Party-ID Di Indonesia}

Dalam kajian (Andre Heywood, 2014:382) Party-ID atau model identifikasi partai kerap digunakan untuk melihat ikatan psikologis yang terjadi antara masyarakat dengan partai-partai politik. Pemilih diasosikan sebagai bagian dari masyarakat yang secara jelas mengidentifikasikan dirinya sebagai bagian dari sebuah partai politik. Jalinanya bersifat jangka panjang dan konsisten dalam setiap momen pemilu. Mereka menganggap partai tersebut adalah representatif sikap politiknya sehingga dalam votting yang diberikan adalah manifestasi dari kerjasama yang saling menguntungkan.

Party-ID mencerminkan sikap atau perasaan seseorang bahwa partai tertentu merupakan identitas politiknya yang harus terus didukung. Secara psikologis mereka siap memberikan sumbangan sumber daya politik yang dimiliki untuk keberlanjutan partai politik yang didukung. Partai Politik akhirnya sangat berkepentingan untuk menjaga dukungan dari pemilih loyal ini. Sebab jika terus terjaga kestabilan dukungan/ suara akan tetap berkesinambungan dalam jangka panjang. Sebaliknya jika tidak mampu dirawat maka potensi ketadiksabilan dukungan semakin besar terjadi.

Dalam model ini, persepsi mengenai sikap politik dibangun atas dasar identifikasi partai. Pilihan politiknya berbanding lurus dengan sikap partai politik. Mereka sulit berubah meskipun ada kampanye negatif yang menyerang partainya. Sosialisasi dan kampanye politik yang mengisi ruang pemikiran mereka berisikan hal-hal yang positif tentang partai yang didukung. Loyalitas dan ikatan-ikatan yang dibangun biasanya stabil dan berkelanjutan.

Problematika politik kepartaiaan Indonesia salah satunya bersumber dari rapuhnya atau rendahnya partyidentification (Party-ID) di Indonesia. Partai politik dinilai telah kehilangan orientasi artikulasi kepentinganya sehingga membuat masyarakat/pemilih enggan mengidentifikasi diri bagian dari partai tersebut khususnya secara ideologis. PartyID berguna untuk mengukur derajat kedekatan warga dengan partai yang linear dengan pilihan politiknya ketika pemilu dilaksanakan. Artinya, pemilih akan menyesuikan pilihan politiknya sesuai dengan sikap partai politik yang didukungnya.

Dalam konteks elektoral Indonesia terjadi penurunan yang cukup tajam dalam hal Party-ID. Survei Saiful Mujani 
Vol..5, No.2, 2019

Doi: https://doi.org/10.24198/cosmogov.v5i2.23293

http://jurnal.unpad.ac.id/cosmogov/index

Research Center (SMRC) yang dilakukan pada Desember 2017 menujukan tingkat Party-ID di Indonesia sangat rendah yakni 11,7 persen. Hal ini tentunya menjadi problem tersendiri dalam upaya konsolidasi demokrasi Indonesia. Fakta tersebut juga menempatkan peringkat Party-ID Indonesia berada pada posisi paling rendah di dunia (Basrianto, 2018). Hal ini memang tidak mengagetkan mengingat partai politik di Indonesia yang semakin kehilangan fungsi dan peran politiknya sebagai agen intermediasi.

Persoalan rendahnya Party-ID menjadi momok besar dalam proses perbaikan kualitas demokrasi di indonesia. Ada beberapa penjelasan untuk ini.

Pertama, rendahnya Party-ID membuat biaya politik tinggi. Rapuhnya ikatan ideologis antara partai dan pemilih membuat uang menjadi salah satu alternatif yang sering digunakan oleh kandidat/partai untuk memperoleh dukungan. Nominalnya pun cukup signifikan. Kajian (Muhtadi, 2018) menyebutkan pada pemilu 2014 sebanyak 33 persen pemilih pernah ditawari uang untuk memilih caleg tertentu. Jika dihitung dari total pemilih 187 Juta pada 2014 sekitar 62 juta menjadi target politik uang. Dengan asumsi sederhana misalnya dari 62 juta pemilih hanya mendapatkan uang dari satu caleg dengan nominal rata-rata 35 ribu, maka jumlah dana yang beredar untuk praktek jual beli suara sebesar 2,17 Triliun. Besarnya praktikmoney politics inilah yang membuat Indonesia menempati peringkat ketiga setelah Uganda dan Benin (theconversation.com, 2018).
Kedua, rendahnya Party-ID secara tidak langsung berimplikasi pada terjadinya praktek korupsi. Tingginya pembiayaan politik yang harus dikeluarkan oleh partai politik/kandidat memaksa mereka untuk mencari modal pengganti. Cara yang lazim digunakan dengan melakukan praktekpraktek pemburuan rente (korupsi) di lembaga-lembaga eksekutif dan legislatif ketika berkuasa. Sudah begitu banyak Kepala Daerah dan anggota legislatif (DPR dan DPD) yang tersandung kasus korupsi dengan alasan mengembalikan modal pencalonan.

Ketiga, rendahnya Party-ID semakin melanggengkan praktek oligarkis di partai politik. Oligarki merujuk pada kekuasaan partai politik di tangan kelompok tertentu (Winters, 2011). Mereka menggunakan partai politik untuk mempertahankan kekuasaaan dan kekayaan. Dengan kemampuan mengkapitalisasi modal dan kekuasaan, partai politik hanya dikelola demi melayani kepentingan kaum oligarkis yakni memperlebar modal yang dimiliki. Lemahnya Party-ID membuat masyarakat yang merasa kurang atau bahkan sama sekali tidak memiliki rasa keperdulian pada partai politik enggan melakukan kontrol. Akibatnya oligarkis semakin berjaya dan menjadi wajar jika pengelolaan partai lebih diorietasikan untuk melayani kepentingan mereka ketimbang kepentingan publik.

Lebih jauh, data yang dipaparkan William Liddle dan Saiful Mujani dalam Voting Behavior in Indonesia since Democratization (2018) menunjukkan ada masanya ketika jumlah masyarakat Indonesia yang merasa dekat atau 
Vol..5, No.2. 2019

Doi: https://doi.org/10.24198/cosmogov.v5i2.23293

http://jurnal.unpad.ac.id/cosmogov/index

mengasosiasikan diri dengan parpol tertentu lebih banyak. Dalam ilmu politik, ukuran yang menggambarkan identifikasi diri dengan partai disebut Party-ID. (Mujani, S., Liddle, R. W., \& Ambardi, 2018).

Studi yang dilakukan Liddle dan Mujani menunjukkan tingkat PartyID Indonesia mendekati Pemilu 1999 mencapai 86 persen. Namun, pada 2003, party-ID di Indonesia turun menjadi 55 persen. Jelang Pemilu 2009, Party-ID di Indonesia hanya 33 persen. Mendekati Pemilu 2014, Party-ID itu hanya sebesar 14 persen. Simpulan yang dapat diambil ialah tingkat party ID yang tinggi pada 1999 terus mengalami penurunan hingga saat ini.

Memudarnya ikatan Party-ID berkontribusi langsung pada masivnya politik uang dalam pemilu. Kajian Burhanuddin Muhtadi (2013) menyebutkan bahwa ada relasi yang positif antara jual beli suara dengan identitas kepartaian (Party-ID). Jika pemilih memiliki Party-ID yang kuat maka potensi jual beli suara ditingkat massa/pemilih dapat dikurangi. Politik yang yang bersifat transaksional yang terjalin antara partai politik/politisi dan pemilih terjadi akibat kegagalan partai politik dalam menampilkan diferensiasi dan positioning ideologis mereka di hadapan pemilih. konsekuensinya, pemilih enggan merepresentasikan diri dalam bagian sebuah partai. Disamping itu, gagalnya partai politik dalam fungsi representasi politik juga turut andil dalam menciptakan kekecewaan ditubuh pemilih yang terakumulasi dalam rendahnya Party-ID.
Fenomena tersebut bisa disebut sebagai deparpolisasi yang sedang menguat di Indonesia saat ini. Proses itu terus berlangsung seiring dengan hilangnya kepercayaan masyarakat terhadap partai politik. Deparpolisasi merupakan gejala psikologis warga yang sudah merasa jauh dengan partai. Mereka tidak mau berjuang bersama partai. Identifikasi seperti itu semakin diperkuat dengan tingkat kepercayaan dan kepuasan publik yang semakin rendah terhadap parpol.

Faktanya partai politik berkontribusi langsung dan signifikan pada kondisi darurat demokrasi di Indonesia sehingga semakin dijauhi oleh publik. Pertama, sistem kepartaian masih dikendalikan oligarki dan transaksional. Oligarki membuat manajemen partai menjadi sangat tertutup, kurang demokratis, tidak transparan serta hanya berorientasi untuk mendukung kelangsungan pertahanan kekayaan kaum oligark. Kaum oligarki ini pulalah yang membuat model bekerja partai di Indonesia mirip kartel (Dan Slater, 2018). Merekalah yang mengkooptasi sistem pemilu demi kepentinganya. Kajian soal kartelisasi Partai Politik Indonesia sebetulnya sudah telah jauh dilakukan melalui tulisan (Kuskridho Ambardi, 2009) yang menyimpulkan bahwa dalam melakukan koalisi kekuasaan partai politik bekerja bukan atas dasar kesamaan ideologis atau platform partai namun pada kesesuian pragmatisme kekuasaan. Kartelisasi membuat perkumpulan koalisi bekerja bukan demi kemaslahatan publik namun demi eksistensi partai. Koalisi dibangun seperti temuan temuan (Richard S. Katz, \& 
Vol..5, No.2, 2019

Doi: https://doi.org/10.24198/cosmogov.v5i2.23293

http://jurnal.unpad.ac.id/cosmogov/index

Peter Mair, 2018) melihat basis utama partai politik dalam membangun relasi adalah demi regulasi yang menguntungkan, keuntungan finansial, dan menguasai institusi kunci negara. Tujuan diatas tentunya bukan atas rasionalisasi kepentingan publik.

Kedua, biaya operasional partai berbentuk seperti industri sehingga menjadi sangat besar. Negara/pemerintah memang melalui Peraturan Pemerintah (PP) Nomor 1 Tahun 2018 menaikan subsidi dari 108 rupiah menjadi 1.000 rupiah per suara untuk DPR dan 1.500 untuk DPRD Kabupaten/Kota. Peningkatan ini cukup drastis meskipun belum mampu secara signifikan biaya operasional partai politik. Akibatnya Partai Politik mencari sumbersumber pembiayaan lain yang salah satunya didapatkan melalui praktek korupsi anggotanya baik di lembaga eksekutif maupun legiskatif.

Ketiga, Partai Politik Indonesia lebih mirip organisasi pemburu rente ketimbang bekerja demi kepentingan publik. Partai Politik lebih disibukan mengejar jabatan kekuasaan politik yang tentu saja berkaitan dengan akses sumber daya modal ketimbang mengadvokasi kepentingan publik. Keempat, mahar politik. pada Pilkada Serentek 2018 setidaknya ada empat kasus besar soal mahar politik. Kasus La Nyala Mataliti pada Pilkada Jatim, Siswandi di Pilkada Cirebon, pasangan John Krisli dan Maryono di Pilkada Palangkaraya 2018 dan Yan Mandenas di Pilkada Biak Numfor 2018 adalah contohnya. Kelima, tentu saja korupsi yang melibatkan kader partai Politik. Hingga kini tercatat beberapa ketua umum partai telah tersangkut kasus korupsi. Dari PKS ada Lhutfi Hasan Ishak (2013), PPP Surya Darma Ali (2014) dan Romahurmuzy (2019), Demokrat Anas Urbaningrum (2014) dan Golkar Setya Novanto (2018). Hal ini diperparah dari semenjak KPK berdiri 200269 persen yang ditangkap KPK adalah kader partai politik.

Citra buruk Partai Politik yang berkelindan dengan rendahnya Party-ID di Indonesia memicu terjadinya politik uang. Relasi masyarakat dan partai politik yang nir ideologis membuat politik uang menjadi jembatan penghubung yang kerap digunakan oleh partai politik dan anarsirnya. Partai politik yang butuh suara harus berhadapan dengan pemilih yang kecewa sebab tidak terjamah oleh programprogram pemberdayaan politik dari partai politik. Kondisi sosial seperti itulah yang membuat partai politik (kader/non kader/tim sukses kandidat) perlu melakukan politik uang agar mendapatkan suara dari pemilih. Disisi lain pemilih menganggap uang merupakan imbalan yang logis dari suara yang diberikan sebab mereka merasa tidak memiliki ikatan ideologis yang kuat dengan partai politik.

\section{SIMPULAN}

Reformasi politik 1998 ternyata justru membuat Party-ID di Indonesia semakin melemah. Meskipun hampir dalam setiap momen elektoral upaya perbaikan terus dilakukan namun politik uang nyatanya tetap terjadi sampai saat ini. Salah satu penyebabnya partai politik yang secara terbuka gagal memerankan dengan maksimal fungsi kaderisasi, komunikasi, 
Vol..5, No.2. 2019

Doi: https://doi.org/10.24198/cosmogov.v5i2.23293

http://jurnal.unpad.ac.id/cosmogov/index

artikulasi serta sosialisasi politik. Pertanda buruk seperti ini harusnya dibaca sebagai koreksi dan evaluasi total bagi keberlangsungan eksistensi partai politik di Indonesia.

Rendahnya Party-ID faktanya berkorelasi langsung dan kuat dengan terjadinya politik uang sampai saat ini. Pemilih yang pragmatis (floating mass) bertautan dengan partai politik yang menginginkan dukungan. Keduanya berlaku pragmatis dengan uang sebagai perekatnya. Dimasa yang akan datang pola seperti ini tetap akan berlangsung selama pendidikan politik masyarakat belum memadai dan partai politik tidak melakukan reformasi kelembagaan secara menyeluruh. Meskipun instrumen hukumnya diperkuat selama belum ada ketegasan sulit mengharapkan politik uang di Indonesia dapat dihilangkan.

Harus diakui politik elektoral di Indonesia sangat padat modal. Kandidat

\section{DAFTAR PUSTAKA}

A15. (2017). Politik Uang Dalam Pilkada 2017. Pinterpolitik.Com. Retrieved from

https://pinterpolitik.com/politikuang-dalam-pilkada-2017/

A37. (2018, August). Ma'ruf Amin, Pragmatisme Jokowi. 10 Agustus. Retrieved from https://pinterpolitik.com/marufamin-pragmatisme-jokowi

Abdul Aziz. (2016). Mewaspadai Masifnya politik Uang. Tirto.Com. Retrieved from https://tirto.id/mewaspadaimasifnya-politik-uang-bSfP

Andre Heywood. (2014). Politik (4). Yogyakarta: Pustaka Pelajar.

Anung, P. (2013). Mahalnya Demokrasi, Memudarnya Ideologi: Potret Komunikasi Politik LegislatorKonstituen. Jakarta: Penerbit Kompas. yang bertarung membutuhkan biaya pemenangan yang sangat besar agar terpilih. Salah satu solusi efektif untuk mencegah pembiayaan politik yang mahal dengan cara partai politik sebagai representasi masyarakat harus mampu memerankan dengan baik fungsi intermediasinya. Jika partai politik secara maksimal mengartikulasikan kepentingan masyarakat maka kepercayaan publik akan meningkat dan pada saat bersamaan politik uang dapat ditekan. Guna mewujudkan hal tersebut maka partai politik perlu melakukan reformasi kelembagaan yang menyeluruh, mendekatkan diri dengan masyarakat melalui program-program pendidikan politik dan pemberdayaan masyarakat yang berkesinambungn, mengadvokasi kebutuhan dan persoalan masyarakat dan tentunya memperjuangkan kepentingan publik dalam kebijakan pemerintah/negara.

Aspinal, E. and M. S. (Ed.). (2016). Electoral Dynamics In Indonesia: Money Politics, Patronage And Clientelism At The Grassroots. Singapura: NUS Press.

Basrianto, F. (2018). Persoalan Party-ID di Indonesia. Retrieved from https://www.theindonesianinstitute. com/persoalan-party-id-diindonesial

Burhanuddin Muhtadi. (2013). Politik Uang Dan Dinamika Elektoral Di Indonesia: Sebuah Kajian Awal Interaksi Antara “ Party-Id” Dan Patron-Klien. Politik LIPI, 10(1), 17-24.

CNN. (2019, April). Polisi Proses 31 Kasus Politik Uang Jelang Pemilu 2019. Retrieved from https://www.cnnindonesia.com/nas ional/20190404170302-12- 
Vol..5, No.2. 2019

Doi: https://doi.org/10.24198/cosmogov.v5i2.23293

http://jurnal.unpad.ac.id/cosmogov/index

383470/polisi-proses-31-kasuspolitik-uang-jelang-pemilu-2019

Dan Slater. (2018). Party Cartelization, Indonesian-Style: Presidential Power-Sharing and The Contingency of Democratic Opposition. Journal of East Asian Studies, 18, 23-46.

Edward Aspinal. (2014). When Brokers Betray: Clientelism, Social Networks, And Electoral Politics In Indonesia. Critical Asian Studies, 46(4), 545-570. Retrieved from tandfonline.com/doi/abs/10.1080/1 4672715.2014.960706

Edward Aspinal. (2019). Democracy For Sale: Pemilihan Umum. Klientelisme, dan Negara di Indonesia. Jakarta: Gramedia.

Eliska Drapalova. (2019). Corruption And The Crisis Of Democracy The Link Between Corruption And The Weakening of Democratic Institutions. Transparency International Anti-Corruption Helpdesk Answer

Firmanzah. (2011). Mengelola Partai Politik (II). Jakarta: Yayasan Obor Indonesia.

Gabrillin, A. (2015). Survei: DPR, Parpol dan Polri, Tingkat Kepuasan Publiknya Paling Rendah. Retrieved from https://nasional.kompas.com/read/ 2015/05/19/19073371/Survei.DPR. Parpol.dan.Polri.Tingkat.Kepuasa n.Publiknya.Paling.Rendah

Huntington, S. (1984). 2. Political Science Quarterly, 99(2), 193-218.

Ihsanuddin. (2019, April). Survei Charta Politika: 45,6 Persen Responden Maklumi Politik Uang. Kompas.Com. Retrieved from https://nasional.kompas.com/read/ 2019/04/05/09373051/surveicharta-politika-456-persenresponden-maklumi-politik-uang

Indikator. (2016). Revisi UU KPK dan Pertaruhan Modal Politik Jokowi.

Jurnaliston, R. (2018). Kinerja Masih Rendah, Partai Politik Diharap Laku Retrieved from https://nasional.kompas.com/read/ 2018/08/07/16454381/kinerjamasih-rendah-partai-politikdiharap-lakukanreformasi?page $=$ all

Kuskridho Ambardi. (2009). Mengungkap Politik Kartel Studi tentang Sistem Kepartaian di Indonesia Era Reformasi. Jakarta: Kepustakaan Gramedia Populer (KPG).

Labolo, M. dan T. I. (2015). Partai Politik dan Sistem Pemilihan Umum Di Indonesia: Teori, Konsep dan Isu Strategis. Jakarta: Raja Grafindo.

Lutfy Mairizal Putra. (2017). Bawaslu Temukan 600 Dugaan Politik Uang pada Pilkada 2017 Retrieved from

https://nasional.kompas.com/read/ 2017/02/14/19334401/bawaslu.te mukan.600.dugaan.politik.uang.pa da.pilkada.2017

Mada Sukmajati, E. Aspinal (ed). (2015). Politik Uang di Indonesia. Yogyakarta: PolGov.

Muhtadi, B. (2018). Riset Tunjukkan Sepertiga Pemilih Indonesia Terima Suap Saat Pemilu. Retrieved from https://nasional.kompas.com/read/ 2018/07/24/06280031/riset-sepertiga-pemilih-indonesiaterima-suap-saat-pemilu?page $=$ all Mujani, S., Liddle, R. W., \& Ambardi, K. (2018). Voting Behavior In Indonesia Since Democratization: Critical Democrats. Cambridge University Press.

Nurjaman, A. (2018). Masa Depan Faksionalisme Politik Golkar Pasca Orde Baru. Jurnal Ilmu Sosial dan Politik, 4(2), 34-48. DOI: $10.22219 /$ sospol.v4i2.5953

Philippe C. Schmitter, T. L. K. (1991). What Democracy Is. . and Is Not. Journal of Democracy, Volume 2(3), 75-88.

Pitkin, H. (1967). The Concept Of Representation (75th ed.). California: California Press.

Prakoso, J. and S. S. (2018). Survey Kepuasan Publik: Kinerja DPR \& Parpol Terendah. Retrieved from https://surabaya.bisnis.com/read/2 
Vol..5, No.2, 2019

Doi: https://doi.org/10.24198/cosmogov.v5i2.23293

http://jurnal.unpad.ac.id/cosmogov/index

0180829/440/832600/survei-

kepuasan-publik-kinerja-dpr-

parpol-terendah

Priyono, U. H. (Ed.). (2014). Merancang Arah Baru Demokrasi Indonesia Pasca Reformasi. Jakarta: Kepustakaan Gramedia Populer (KPG).

RFQ. (2014, April). Kasus Pidana Pemilu di Polri Didominasi Politik Uang. Retrieved from https://www.hukumonline.com/beri ta/baca/t53563f475f480/kasuspidana-pemilu-di-polrididominasi-politik-uang/

Richard S. Katz and Peter Mair. (2018). Democracy and the Cartelization of Political Parties. Oxford: Oxford University Press.

Sergiu Gherghina. (2015). Party Organization and Electoral Volatility in Central and Eastern Europe Enhancing Voter Loyalty. Oxon: Routledge.

Sutrisno Hadi. (2001). Metodologi Research Jilid III (III). Yogyakarta: Andi Offset.

Tan, P. J. (2018). The New Normal: Indonesian Democracy Twenty
Years after Suharto.

Https://Kyotoreview.Org/.

Retrieved from

https://kyotoreview.org/issue-

24/new-normal-indonesiandemocracy-after-suharto/

Tashandra, N. (2017). Survei Kepuasan Publik Terhadap Institusi, DPR Nomor Berapa Ya Artikel ini telah tayang di tribunkaltim.co dengan judul Survei Kepuasan Publik Terhadap Institusi, DPR Nomor Berapa Ya?,. Retrieved from https://kaltim.tribunnews.com/2017 /11/27/survei-kepuasan-publikterhadap-institusi-dpr-nomorberapa-ya

Trian, H. (2018). Survei Kepuasan Publik ke Lembaga Negara: TNI Dapat Nilai A, DPR Dapat C. Retrieved from

https://nasional.okezone.com/read/ 2018/05/28/337/1903459/surveikepuasan-publik-ke-lembaganegara-tni-dapat-nilai-a-dprdapat-c

Winters, J. (2011). Oligarki (terj). Jakarta: Gramedia. 